\title{
Pott's disease associated with large and multiple abscesses in a 30-year-old migrant from Chad
}

\author{
Anne Conrad, ${ }^{1,2,3,4}$ Tristan Ferry, $^{1,3,2,4}$ Florence Ader, $^{1,3,2,4}$ Florent Valour, $^{1,3,2,4}$ on behalf \\ of the Lyon BJI Study group.
}

${ }^{1}$ Infectious Diseases

Department, Hospices Civils de

Lyon, Lyon, France

${ }^{2}$ Université Claude Bernard Lyon

1, Lyon, France

${ }^{3}$ Centre Interrégional de Référence des Infections Ostéoarticulaires complexes (CRIOAc Lyon), Hospices Civils de Lyon, Lyon, France

${ }^{4}$ Centre International de Recherche en Infectiologie, CIRI, Inserm U1111, CNRS UMR 5308, ENS de Lyon, UCBL1, Lyon, France

\section{Correspondence to} Dr Tristan Ferry,

tristan.ferry@univ-lyon1.fr

Accepted 5 October 2017

\section{Check for updates}

To cite: Conrad A, Ferry T, Ader F, et al. BMJ Case Rep Published Online First: [please include Day Month Year]. doi:10.1136/bcr-2017222420

\section{DESCRIPTION}

After a 1-year history of increasing mechanical back pain, a 30-year-old Chadian man with no medical record progressively developed a voluminous paravertebral mass (figure 1A). He described night sweats without fever for several months associated with a $20 \mathrm{~kg}$ weight loss (admission weight at 68 $\mathrm{kg}$ ). Physical examination revealed no neurological defect. Laboratory tests showed a biological inflammatory syndrome with $\mathrm{C}$ reactive protein (CRP) plasmatic level at $80 \mathrm{mg} / \mathrm{L}$ and fibrinogen at $5.1 \mathrm{~g} / \mathrm{L}$. A vertebral MRI showed a T11-T12 vertebral osteomyelitis with a discal and corporeal abscess surrounded by important adjacent bone oedema, epiduritis causing mild spinal cord compression, as well as voluminous, prevertebral $(12 \times 8 \times 5 \mathrm{~cm})$, left psoas $(9 \times 8 \times 8 \mathrm{~cm})$ and retrovertebral $(16 \times 5 \times 4 \mathrm{~cm})$ liquid collections with peripheral contrast enhancement, suggestive of abscesses (figure 1B-D). Culture of the punctured collection of the retrovertebral abscess yielded multisusceptible Mycobacterium tuberculosis. Body scan revealed no other disease localisation. HIV serological test was negative and CD4 + T cell count $\left(609 / \mathrm{mm}^{3}, 51 \%\right.$ of total lymphocytes) was normal. A combination of rifampin $(10 \mathrm{mg} / \mathrm{kg} / \mathrm{d})$, isoniazid $(4.4 \mathrm{mg} / \mathrm{kg} / \mathrm{d})$, pyrazinamide $(25 \mathrm{mg} / \mathrm{kg} / \mathrm{d})$ and ethambutol $(20 \mathrm{mg} / \mathrm{kg} / \mathrm{d})$ was initiated. Two months later, as the control MRI was strictly stable, the collections were drained, but quickly reconstituted. At that time, drained pus remained sterile in culture. The patients declared a good observance, and drug monitoring showed rifampin, isoniazid, pyrazinamide and ethambutol plasmatic levels within the therapeutic targets. After
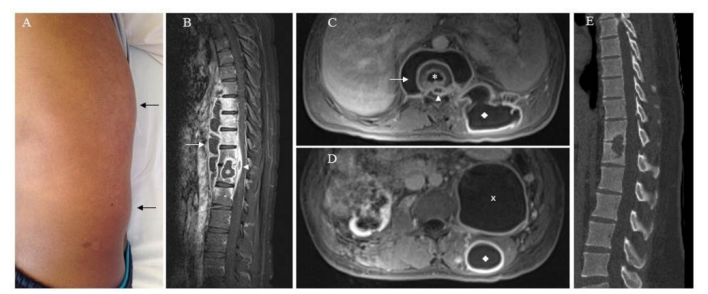

Figure 1 Historical Pott's diseases presenting as voluminous clinical left paravertebral tumefactions ( $A$, arrows), with T1-weighted vertebral MRI with gadolinium (B to D) disclosing a T11-T12 osteomyelitis with voluminous corporeal (asterisk), prevertebral (arrow), spinal epidural (arrow head), retrovertebral (lozenge) and left psoas (cross) abscesses. One-year after treatment completion, a contrast-enhanced CT scan (E) showed an osteolytic cavity with tissue content bridging T11-T12 vertebral bodies.

\section{Learning points}

Pott's disease is a classical but rare presentation of extrapulmonary tuberculosis.

- Insidious evolution can lead to the formation of voluminous paravertebral abscess.

- In the absence of neurological defect, surgical or radiological drainage is inefficient, and medical management alone is sufficient, although clinical and radiological recoveries may be differed.

6 months of therapy, CRP finally turned negative and patient's weight began to rise. Treatment was simplified to a combination of rifampin and isoniazid. After remaining strictly stable for 7 months, perispinal collections quickly collapsed, until disappearing at the 9-month control MRI. Antimicrobial therapy was continued for a total duration of 12 months. On treatment discontinuation, the patient was doing well, with a body weight at $82 \mathrm{~kg}$. In a 1-year follow-up after treatment stop, no clinical or radiological sign of relapse was noted, while a CT scan displayed nearly fused T11-T12 vertebral bodies with a central, osteolytic cavity and without posterior wall recession (figure $1 \mathrm{E}$ ).

Pott's disease is a classical but rare presentation of tuberculosis, accounting for about $5 \%$ of total extrapulmonary localisation. ${ }^{1}$ It can develop insidiously, leading to the formation of voluminous cold paravertebral abscesses, characterised by low inflammatory symptoms and low-grade pain. Surgical or radiological evacuation of cold abscesses is not recommended, as usually ineffective, as confirmed in our patient. ${ }^{2} 3$ Surgical management must consequently be restricted to patients with neurological defect, important spinal instability or failure of medical management. Treatment duration is debated, usually recommended for 6 to 9 months, but can be prolonged in most severe cases such as our patient. ${ }^{1}$

Acknowledgements Lyon Bone and Joint Infection Study Group: Coordinator: Tristan Ferry; Infectious Diseases Specialists - Tristan Ferry, Florent Valour, Thomas Perpoint, André Boibieux, François Biron, Patrick Miailhes, Florence Ader, Agathe Becker, Sandrine Roux, Claire Triffault-Fillit, Fatiha Daoud, Johanna Lippman, Evelyne Braun, Christian Chidiac, Yves Gillet, Laure Hees; Surgeons - Sébastien Lustig, Elvire Servien, Yannick Herry, Romain Gaillard, Antoine Schneider, Michel-Henry Fessy, Anthony Viste, Philippe Chaudier, Romain Desmarchelier, Tanguy Mouton, Cyril Courtin, Lucie Louboutin, Sébastien Martres, Franck Trouillet, Cédric Barrey, Francesco Signorelli, Emmanuel Jouanneau, 
Timothée Jacquesson, Ali Mojallal, Fabien Boucher, Hristo Shipkov, Mehdi Ismail, Joseph Chateau; Anesthesiologists - Frédéric Aubrun, Isabelle Bobineau, Caroline Macabéo; Microbiologists - Frederic Laurent, François Vandenesch, Jean-Philippe Rasigade, Céline Dupieux; Imaging - Fabien Craighero, Loic Boussel, Jean-Baptiste Pialat; Nuclear Medicine - Isabelle Morelec, Marc Janier, Francesco Giammarile; PK/ PD specialists - Michel Tod, Marie-Claude Gagnieu, Sylvain Goutelle; Prevention of infection - Solweig Gerbier-Colomban, Thomas Benet; Clinical Research Assistant Eugénie Mabrut

Contributors $A C$ and FV wrote the manuscript and performed the literature review. AC, TF, FA and FV took care of the patient, and read, significantly amended and approved the final version of the manuscript.

Competing interests None declared.
Patient consent Obtained.

Provenance and peer review Not commissioned; externally peer reviewed.

(c) BMJ Publishing Group Ltd (unless otherwise stated in the text of the article) 2018. All rights reserved. No commercial use is permitted unless otherwise expressly granted.

\section{REFERENCES}

1 Leonard MK, Blumberg HM. Musculoskeletal tuberculosis. Microbio/ Spectr 2017;5.

2 Bhojraj S, Nene A. Lumbar and lumbosacral tuberculous spondylodiscitis in adults. Redefining the indications for surgery. J Bone Joint Surg Br 2002;84:530-4.

3 Nene A, Bhojraj $S$. Results of nonsurgical treatment of thoracic spinal tuberculosis in adults. Spine J 2005;5:79-84.

Copyright 2017 BMJ Publishing Group. All rights reserved. For permission to reuse any of this content visit

http://group.bmj.com/group/rights-licensing/permissions.

BMJ Case Report Fellows may re-use this article for personal use and teaching without any further permission.

Become a Fellow of BMJ Case Reports today and you can:

- Submit as many cases as you like

- Enjoy fast sympathetic peer review and rapid publication of accepted articles

- Access all the published articles

- Re-use any of the published material for personal use and teaching without further permission

For information on Institutional Fellowships contact consortiasales@bmjgroup.com

Visit casereports.bmj.com for more articles like this and to become a Fellow 